\title{
EFFECTS OF BODY COMPOSITION ON THE MANIFESTATION OF STATIC STRENGTH IN GIRLS OF LOWER ELEMENTARY SCHOOL AGE
}

\author{
Akoš Taboroši ${ }^{*}$ \\ Grammar School for Talented Students “Kosztolányi Dezső”, Subotica, Serbia
}

\begin{abstract}
This study presents the results of the analysis of the effects of body composition on the manifestation of static strength in girls of lower elementary school age. The sample consisted of 63 girls aged seven. All the girls were from Subotica and attend elementary schools. Height was measured by the use of Martin's anthropometer, weight was measured by the use of InBody 230. The measures of body composition (body fat, total body water and skeletal muscle mass) were assessed by InBody 230, a device which functions on the base of bioelectrical impedance. The static strength of arms and shoulder area was assessed by „Bent-arm hang” test. The results pointed to the statistically significant effects of the body composition on the manifestation of static strength in girls of lower elementary school age.
\end{abstract}

Keywords: body composition, static strength, girls

\section{Introduction}

The contemporary conditions have a negative influence on people's lives because they spend too much time sitting in their workplace, in front of the TV and computer or in a car. Most of the population suffer from the consequences of the lack of physical activity and as hypokinesis itself leads to obesity and the accumulation of emotional stress, the influence of these three factors make the commonest cause of various deseases and poor life expectancy in modern times (Stojiljković, Mandarić, Todorović, \& Mitić, 2010). In the developed countries the average level of motor abilities is constantly decreasing due to the prevailance of sedentary lifestyle. People who lack recreative exercise have poor motor abilities that has cosequences on their health and quality of life in general.

\footnotetext{
* Corresponding author. Grammar School for Talented Students "Kosztolányi Dezső", Trg žrtava fašizama 21, 24000 Subotica, Serbia, e-mail: takos83@freemail.hu

(C) 2013 Faculty of Sport and Physical Education, University of Novi Sad, Serbia
} 
Body weight itself is not a reliable criterium for obesity considering the fact that people of the same weight and height may have a significantly different body composition, that is to say a different proportion of body fat and lean body mass.

The majority of traditional methods of estimating body composition is based on a twocomponent model which suggests that the total body mass consists of two factors: fat body mass and lean body mass. Lean body mass is calculated from the muscles, skeleton and internal organs, while fat body mass consists of "relevant" and "irrelevant" fat, "irrelevant" fat meaning the subcutaneous fat tissue, yellow bone marrow and the abdominal visceral fat.

The size of fat mass is an extremely changeable category depending on age, gender and the level of physical activity. An increase in body fat mass may not as a rule result in the increase of total body mass. Sometimes the amounts of body fat increase, while lean body mass, usually muscle mass remains constant, which leads to normal weight obesity. On the other hand people having excess body weight for their height do not necessarily have to be obese (they do not necessarily have excess amount of body fat), but the weight gain may be the result of a bigger proportion of lean body mass as result of a more developed skeletal muscle system and the skeleton itself.

The effects of gender differences on the percentage of body mass become evident at an early age. Girls have greater amounts of fat tissue in the total body mass, mainly stored in the bust and hip area. The amount of body fat in girls increases significantly during adolescence. In puberty the amount of fat mass grows twice as much in girls than in boys.

Strength can be defined as an ability to resist an external force through the tension of muscles (Nićin, 2000). Static strength is the ability of maintaining a greater isometric muscle contraction which holds the body in a certain posture (Nićin, 2000).

Static strength develops through isometric contractions. In this type of contractions there is no change in the muscle length. Static strength has a rather low congeniality coefficient (about 56\%) (Krsmanović \& Berković, 1999), which means that it can be significantly improved by physical exercise. The sensitive period for improving the static strength in girls is between the age of seven and fifteen.

Body composition, i.e. the ratio of lean body mass to fat body mass, changes through life and it can also be modified by external (exogenous) factors like diet, physical exercise and sports activity. Physical exercise that aims the reduction of excess body weight and subsequently the excess fat is based on cyclical aerobic activities in combination with strength exercises. The improvement of strength generally results in the increase of muscle mass. Girl have lower muscle strength and manifest less strength.

Babin, Bavčević, \& Moretti (2006) conducted the canonical correlation analysis of motor abilities and anthropometric characteristics on a sample of 294 examinees. Motor abilities were analysed through the explosive strength of lower limbs, the repetitive strength of the trunk and static strength of arms and shoulder area. From the aspect of the anthropometric characteristics subcutaneous fat tissue was also calculated. Obtained results draw the attention to the fact that there is a significant negative correlation between the amount of subcutaneous fat and the ability to perform a strength type motor test.

Bala, Jakšić, \& Popović (2009) conducted a research which analysed the relations of morphological characteristics and motor abilities of pre-school children. The sample consisted of 1170 children of pre-school age, 565 boys and 605 girls. Results showed that among the girls of the youngest age there was a significant negative correlation between the amount of subcutaneous body fat and the static strength of arms and shoulder area. Also, between the age of 4,5 and 5,5 there was a significant negative correlation between the amount of subcutaneous body fat and the static strength of arms and shoulder area. 
Madić et al. (2011) measured the indicators of body composition on a sample consisting of 120 girls aged 11-12. They also measured height and weight, while the ability of performing complex movement structures was estimated through the ability of performing exercises on gymnastic apparatus and floor after a short training period. The results of the research showed that body mass significantly determined the ability of preforming complex movement structures in girls aged 11-12. Girls who had better performing abilities were of statistically significantly less weight, less body fat and greater amount of muscles and body water.

The aim of this research was to determine the effects of body composition on the manifestation of static strength in girls of lower elementary school age.

\section{Method}

\section{Sample of participants}

The sample consisted of 63 female participants, first-grade students of elementary school. All the examinees were from Subotica, from two elementary schools "Majšanski put" and "Jovan Jovanović Zmaj". The participants followed the national curriculum for the first grade of primary schools which included three physical education lessons per week. The age of participants was determined on the base of decimal years, and mean $(\mathrm{M}=7,54)$ and standard deviation $(\mathrm{SD}=0,41)$ were also calculated.

\section{Measures}

The following athropometric measures were used:

1. Height (cm) - measured by Martin`s anthropometer

2. Weight $(0.1 \mathrm{~kg})$ - measured by InBody 230 electronic scales (Biospace Co., Ltd, Seul, Korea)

Body composition was calculated by the following devices:

1. Fat $(0.1 \mathrm{~kg})$ - by InBody 230 (Biospace Co., Ltd, Seoul, Korea)

2. Total Body Water $(0.1 \mathrm{~kg})$ - by InBody 230 (Biospace Co., Ltd, Seoul, Korea)

3. Skeletal Muscle Mass (0.1 kg) - by InBody 230 (Biospace Co., Ltd, Seoul, Korea)

Body composition was estimated by InBody 230 equipment (Biospace Co., Ltd, Seoul, Korea), which functions on the basis of bioelectrical impedance. Bioelectrical impedance is nowadays a widely used method for determining body composition. It is based on the presumption that electric resistance is the highest in fat tissue, since conductivity depends on the amount of water in the tissue, which is the lowest in the lean mass. The procedure itself is simple, noninvasive, quick and does not demand an extremely expensive equipment. This method measures body composition by sending an extremely low, safe alternating electrical current of $50 \mathrm{mHz}$, current strength $800 \mathrm{~m}$, through the body. The current passes freely through the fluids contained in muscle tissue, but encounters difficulty/resistance when it passes through fat tissue. Since fat tissue contains little water it will have the highest resistance. Examinees stand with their arms stretched away from the body holding the electrodes which are in the form of sensors. After a few seconds, the equipment automatically calculates all the components of body composition. 
Motor test used in the study was:

1. Bent-arm hang $(0.1 \mathrm{~s})$ - for static strength of arms and shoulders

This motor test was carried out according to the instructions of Bala, Stojanović, \& Stojanović (2007), adjusted to younger children.

Bent-arm hang: Children grasp the overhead bar by the help of an assistant and use of a chair, using underhand grip in shoulder width with their chin over the bar. After establishing the starting body position they have to keep the bent-arm hang the longest possible, without any further assistance. The test is ended when the chin gets under the overhead bar. The examiner stands beside and in front of the examinee, encouraging them to hold the described position as long as possible and measures time. The result is measured in decimal seconds.

\section{Procedure}

This cross-sectional study was carried out in school gyms. The tests were conducted by physical education teachers from Subotica and their trained assistants. Prior to testing parents gave written approval in accordance with the requirements of the Declaration of Helsinki (Bala, 2008). Height and weight were measured first, then body composition was estimated, and finally static strength was tested.

\section{Data analysis}

The data were processed with proper statistical procedure SPSS 13.0. Central and dispersion statistics were stated first. Regression analysis was used to determine the effect of body composition on the manifestation of static strength in girls of lower elementary school age.

\section{Results}

Table 1. shows the descriptive statisctics data of all measured variables (body composition variables and Bent-arm hang variable).

Table 1.

Basic descriptive statistics

\begin{tabular}{lcccc}
\hline \multicolumn{1}{c}{ VARIABLES } & M & SD & MIN & MAX \\
\hline Years of age in decimals & 7.54 & 0.41 & 6.93 & 8.91 \\
Bent-arm hang $(0.1 \mathrm{~s})$ & 111.25 & 98.85 & 0 & 556 \\
Fat $(0.1 \mathrm{~kg})$ & 5.84 & 4.29 & 1.70 & 25.50 \\
Total Body Water $(0.1 \mathrm{~kg})$ & 16.31 & 2.50 & 12.60 & 24.70 \\
Skeletal Muscle Mass $(0.1 \mathrm{~kg})$ & 11.04 & 2.05 & 8.10 & 17.60 \\
\hline
\end{tabular}

Abbreviations: $\mathrm{M}$ - mean; SD - standard deviation; MIN - minimum values; MAX - maximum values 
On the basis of the descriptive analysis of variables it can be stated that girls were very similar (homogenous) in terms of some variables, but also significantly different (heterogenous) in terms of other variables. Similarities were detected in terms of Total Body Water and Skeletal Muscle Mass, while they were very heterogenous in terms of Fat and Bent-arm hang variables. Some girls were categorised as obese, while others suffered of serious malnutriton. Higher variability of Bent-arm hang motor test results in girls made the sample less homogenous, which means that the girls did not show the same development level of strength of arms and shoulder area. Considering the highest and lowest Bent-arm hang variable values it may be stated that some of the girls were completely unable to perform the mentioned motor test, while others performed it quite successfully.

Table 2 shows the results of regression analysis for determining the effect body composition on the manifestation of static strength in girls of lower elementary school age.

Table 2.

Regression analysis of Bent-arm hang variables

\begin{tabular}{lcc}
\hline PREDICTOR VARIABLES & Beta & p \\
\hline Total Body Water & -0.11 & 0.69 \\
Fat & -0.46 & 0.00 \\
Skeletal Muscle Mass & 0.02 & 0.96 \\
\hline \multicolumn{2}{r}{$=0.519 \mathrm{R}^{2}=0.269 \mathrm{P}=0.00$} & \\
\hline
\end{tabular}

Abbreviations: $\mathrm{R}$ - coefficient of multiple correlation; $\mathrm{P}$ - level of statistical significance for coefficient of multiple correlation; $\mathrm{R}^{2}$ - coefficient of determination; Beta - standardised regression coefficient; $\mathrm{p}$ - level of statistical significance for Beta standardised coefficient

The results of regression analysis of Bent-arm hang motor test in girls of lower elementary school age showed a statistically significant effect of predictive system of varibles on the criteria variable, i.e. a significant effect of body composition on the manifestation of static strength. The calculated value of multiple correlation coefficient is $\mathrm{R}=0.519$, which is a rather high positive correlation. It proves that body composition highly determines the variable results of Bent-arm hang. The prediction system of variables gave explanation for $26.9 \%$ of criteria variability, while in the case of the remaining variability of criteria variables other characteristics may be responsible, which were not included in the applied system (for example, other anthropometric characteristics, motivation to perform the motor test more successfully, etc.). The greatest and statistically most significant effect on the criteria variable of Bent-arm hang in girls was caused by the variable of the total amount of body fat, with $p=0.00$. Negative values of Beta coefficient point to a negative effect of total amount of body fat on the manifestation of static strength in girls of lower elementary school age. 


\section{Discussion}

This study has proved that the fat has adverse effects on the manifestation of static strength in girls of lower elementary school age. Girls whose body contains a greater amount of fat achieved poor results in the appointed motor task. The obtained results were expected and therefore logical, since fat, as a superfluous burden acts as an inhibitory factor in performance. Regular physical activity on different levels brings positive changes both in terms of body composition and in physiological values (Parizková, 1973).

In the period between 1999 and 2000, 15\% of the children aged six to nineteen were found obese, which is three times more than in 1980 . Today, more than $10 \%$ of children aged from two to five suffer of obesity, compared to the year of 1994, when only $7 \%$ were in this category. It is considered that for another $15 \%$ of the children obesity is an imminent danger. An average child in the United States does less than 15 minutes of vigorous physical activity a day, and only 43 minutes of moderate activity. The average time children spend in front of television is 17 hours a week, not counting the time spent playing video or computer games. As result many children cannot perform press-ups or sit-ups. It causes much trouble for them to do relatively mild exercise where they have to use their own body as load. Such reduced abilities have further adverse effects on their willingness to work out and their self-confidence. Training significantly improves body composition and increases physical activity. In fact, strength training helps reducing body fat and increases the amount of muscles. Although, it is true that these changes may lead to a mild weight gain, since muscles are heavier than fat. Moreover, strength is significantly improved, and the increase of the measures of the upper body is insignificant, while the lower body measures do not change. Nerves are a primary mechanism that affect the improvment of strength of children in puberty. It has been found that a significant improvement of strength before puberty does not result in according increase in the morphological measures of limbs. Without the appropriate concentration of the hormone of growth and androgen which stimulate the increase of muscle tissue, at that age children hardly increase the muscle mass. Girls may have a different approach to strength training. They usually associate strength training with masculine features, therefore many of them are unvilling to do strength training. For this reason it is important to explain what they gain by strength training as to help them get rid of prejudices. Girls have to be told that they cannot increase their muscles in a way boys do, since they do not have the same amounts of testosterone and muscle cells (Zatsiorsky, \& Kraemer, 2006).

Body composition is a lot more sensitive to the effects of physical activity than height and weight. In physically active girls the amount of body fat is less, while the amount of lean mass is greater than in non-athletic girls. It must be stressed that such positive changes occur only as result of systematic work-out. Regular physical activity does not speed up the growth of longitudinal dimensions, but it increases the active (muscle) mass of he body and reduces body fat (Mészáros, 2010).

The results of this research are supported by the study of Vajda (2008) who in her work proved that the success in performing motor exercises depends on the size of certain body parts, build and body composition. A great amount of body fat has an advert effect on physical performance. Extremely poor physical performance can only partly be explained by a great amount of body fat. Inactive way of life (hypokinesis) has an even more significant effect, and in this term the number of physical education lessons and the system of physical education in schools does not provide solution.

The results of this research prove that there is a statistically significant effect of body composition on the manifestation of static strength in girls of lower elementary school age. 


\section{References}

Babin, J., Bavčević, T., \& Moretti, V. (2006). Kanoničke relacije latentne morfološke strukture i varijabli snage učenica u dobi od šest do sedam godina [Canonical relations of the latent morfological structure and strength variables in girl pupils aged six-seven]. U V. Findak (Ur.), 15. Ljetna škola kineziologa Republike Hrvatske (pp. 62-66). Rovinj: Hrvatski kineziološki savez.

Bala, G. (2008). Uspešno pisanje u kineziologiji [Successful Writing in Kinesiology]. Novi Sad: Fakultet sporta i fizičkog vaspitanja.

Bala, G., Jakšić, D., \& Popović, B. (2009). Trend relacija morfoloških karakteristika i motoricičkih sposobnosti predškolske dece [Trend of relations between morphological characteristics and motor abilities of pre-school children]. U G. Bala (Ur.), Relacije antropoloških karakteristika i sposobnosti predškolske dece (pp. 61-112). Novi Sad: Fakultet sporta i fizičkog vaspitanja.

Bala, G., Stojanović, M., \& Stojanović, M. (2007). Merenje i definisanje motoričkih sposobnosti dece [Measurement and Definement of Motor Abilities of Children]. Novi Sad: Fakultet sporta i fizičkog vaspitanja.

Krsmanović, B., \& Berković, L. (1999). Teorija i metodika fizičkog vaspitanja [Theory and Methodics of Physical Education]. Novi Sad: Fakultet fizičke kulture.

Madić, D., Popović, B., Tumin, D., Obradović, J., Pantović, M., \& Cvetković, M. (2011). Uticaj telesne kompozicije na izvođenje složenih kretnih struktura kod devojčica uzrasta 11-12 godina [Effects of body composition on the performance of complex movement exercises in girls aged 11-12]. Glasnik Antropološkog društva Srbije, 46, 287-292.

Mészáros, Zs. (2010). A szomatikus fejlödés, a testösszetétel és a motorikus teljesitmény változása alsó tagozatos fiúknál [Somatic development, body composition, and change of motor achievement of junior school age boys]. Doctoral dissertation, Budapest: Semmelweis Egyetem Doktori Iskola.

Nićin, Đ. (2000). Antropomotorika. [Anthropomotorics]. Novi Sad: Fakultet fizičke kulture.

Parizková, J. (1973). Body composition and exercise during growth and development. In Rarick G.L. (Ed.), Physical Activity, Human Growth and Development (pp. 97-124). New YorkSan Francisco - London: Academik Press.

Stojiljković, S., Mandarić, S., Todorović, K., \& Mitić, D. (2010). Efekti primene "omnibus" aerobika na telesnu kompoziciju žena [The effects of "omnibus" aerobics application on women`s body compositin]. Fizička kultura, 64(2), 59-67.

Vajda, I. (2008). A motorikus teljesitmények és az antropometriai jellemzök kapcsolata 7-10 éves nem sportoló gyermekeknél [The correlation between motor performance and anthropometric features with 7-10 year-old, non-athletic children]. Doctoral dissertation, Budapest: Semmelweis Egyetem Sporttudományi Doktori Iskola.

Zatsiorsky, M. V. \& Kraemer, J. W. (2006). Science and Practice of Strength Training [Nauka i praksa u treningu snage]. Beograd: Data Status. 